\title{
KINERJA SUPERVISOR DAN KREATIVITAS GURU PAI
}

\author{
PAGGA, ABD RAHMAN GETTENG, KHALIFAH MUSTAMI, \\ ST. SYAMSUDDUHA \\ Program Pascasarjana UIN Alauddin Makassar \\ Email: paggakantoro@gmail.com, rahmangetteng@gmail.com, \\ muhkhalifahmustami@uin-alauddin.ac.id, st.syamsudduha@uin-alauddin.ac.id \\ (Article History) \\ Received September 15, 2020; Revised September 20, 2020; Accepted September 21, 2020
}

\begin{abstract}
:
This study aims to determine the supervisor's performance and the creativity of the Islamic Religious Education teachers at SMAN Sinjai Regency. This research used qualitative research. The data analysis technique used is data reduction, data presentation, data collection using descriptive exploratory analysis techniques, and inductive qualitative methods. The result was found that the supervisor's performance in the preparation of supervisor program planning had been compiled in an accurate manner and the implementation of supervisor supervision had been implemented in the field continuously. PAI teacher creativity in SMA Negeri Sinjai Regency has increased through several programs that have been carefully prepared by supervisors. The supporting factors for supervisors in increasing the creativity of PAl teachers are the existence of supervisory standardization arrangements and the presence of collectors. As for the inhibiting factors for supervisors, namely the number of target schools that are too many, the busyness of the supervisors outside the supervision program, the number of supervisors is still low, and the teacher's perception of supervision activities is still not good.
\end{abstract}

Keywords: Supervisor Performance, Teacher Creativity, The Quality of Teacher

\section{PENDAHULUAN}

endidikan merupakan sarana yang sangat strategis dalam melestarikan sistem nilai yang berkembang dalam masyarakat. Proses pendidikan tidak hanya memberikan pengetahuan dan pemahaman (transfer of knowledge and under-standing) kepada peserta didik, tetapi lebih diarahkan pada pembentukan sikap, perilaku, dan kepribadian peserta didik itu sendiri. Damopolii (2011, h. 47) menjelaskan bahwa jika pendidikan hanya ditekankan pada aspek pengajaran saja, maka output yang dihasilkan akan kosong dari berbagai dimensi nilai yang hidup dalam masyarakat, baik nilai agama, etika, maupun adat istiadat. Karena itu, pada gilirannya nanti ada generasi yang tidak bisa membedakan kebaikan dan keburukan.

Menurut Getteng (2010, h. 14), “Pendidikan yang bermutu adalah ketika peserta didik secara aktif mengembangkan potensi dirinya untuk memiliki kekuatan spritual keagamaan, pengendalian diri, kepribadian, akhlak mulia, serta keterampilan yang diperlukan dirinya, masyarakat, bangsa dan negara, yang dilakukan secara sadar dan terencana". Dalam hal ini peserta didik diposisikan 
sebagai subjek pendidikan dan guru harus menyesuaikan diri dengan potensi peserta didik. Pendidik perlu mengeksplor dan meng-upgrade potensi dirinya agar berkompeten dalam mengelola pembelajaran. Pengembangan potensi pendidik menjadi agent of change yang inovatif, mandiri, dan kreatif, tidak terlepas dari perhatian, arahan, dan bimbingan pihak yang berkompeten dalam kegiatan supervisi. Orang yang melakukan supervisi disebut supervisor (pengawas).

Supervisor atau pengawas pada satuan pendidikan/sekolah adalah pejabat fungsional yang berkedudukan sebagai pelaksana teknis untuk melakukan pengawasan pendidikan terhadap sejumlah sekolah tertentu yang ditunjuk/ditetapkan dalam upaya meningkatkan kualitas proses dan hasil belajar/bimbingan untuk mencapai tujuan pendidikan (Pandong, 2013). Kegiatan supervisi yang dilakukan oleh supervisor bertujuan agar pendidik mengetahui dengan jelas tujuan dari pekerjaannya dalam mendidik, mengenai apa yang hendak dicapai dari pelaksanaan pendidikan tersebut, serta mengetahui pula fungsi dari pekerjaan yang pendidik lakukan. Hal ini dimaksudkan untuk membantu pendidik agar lebih fokus pada tujuan yang ingin dicapai dalam pendidikan dan menghindarkan dari pelaksanaan pendidikan yang tidak relevan dengan tujuan pendidikan. Sutisna dalam Sagala (2009, h. 229) mengemukakan bahwa supervisi sebagai segala usaha yang diarahkan kepada penyediaan kepemimpinan bagi para guru dan tenaga kependidikan lain dalam perbaikan pengajaran, melibatkan stimulus per-tumbuhan profesional dan perkembangan dari para guru, seleksi dan revisi tujuan-tujuan pendidikan, bahan pengajaran, dan metode-metode mengajar, dan evaluasi pengajaran.

Makawimbang (2011, h. 101) mengemukakan bahwa seorang supervisor yang dikatakan profesional dapat menjalankan tugasnya secara efektif untuk mencapai tujuan supervisi, maka supervisor harus mengetahui, memahami, serta memilih model, tipe, pendekatan, dan teknik supervisi yang cocok dan sesuai dengan tujuan pelaksanaan yang akan dicapai, hal tersebut dikarenakan dalam pelaksanaan supervisi, para supervisor dihadapkan dengan berbagai macam karakteristik guru.

Menurut Suhardan (2010, h. 36-39), “Supervisi merupakan pengawasan terhadap pelaksanaan kegiatan teknis edukatif di sekolah, bukan sekedar pengawasan terhadap fisik material". Sedangkan menurut Rikunto dalam Nurhayati, Siraj, dan Yaumi (2020) supervisi merupakan pengawasan terhadap kegiatan akademik yang berupa proses pembelajaran, pengawasan terhadap guru dalam belajar, pengawasan terhadap peserta didik yang belajar, dan pengawasan terhadap situasi yang menyebabkannya. Hal ini sejalan Sahertian (2010, h. 17) mengatakan "Supervisi adalah suatu usaha menstimulasi, mengkordinasi dan membimbing secara kontinu pertumbuhan guru-guru di sekolah baik secara individu maupun secara kolektif, agar lebih mengerti dan lebih efektif dalam mewujudkan seluruh fungsi pengajaran". Aktivitas yang dilakukannya yaitu dengan mengidentifikasi kelemahan-kelemahan pembelajaran untuk diperbaiki, apa yang menjadi 
penyebabnya dan mengapa guru tidak berhasil melasanakan tugasnya dengan baik. Berdasarkan hal tersebut kemudian diadakan tindak lanjut yang berupa perbaikan dalam bentuk pembinaan.

Berdasarkan beberapa pengertian tersebut, dapat disimpulkan bahwa supervisor adalah orang yang melakukan pengawasan pelaksanaan teknisi pendidikan pada satuan pendidikan/sekolah agar dapat mewujudkan fungsi pembelajaran/pengajaran yang efektif.

Danim dan Khairil (2010, h. 158) mengemukakan supervisor memiliki empat fungsi penting yang harus diperankan dalam setiap tugasnya, yaitu: administratif function (fungsi administrasi), evalution process (proses evaluasi), teaching function (fungsi pengajaran) and role of consultan (peran kepengawasan). The administratif function merupakan fungsi pengawasan umum terhadap kualitas kinerja guru dalam membelajarkan peserta didiknya. The evalution process membantu guru untuk dapat memahami peserta didik bermasalah yang perlu mendapat bantuan dalam memecahkan masalah belajarnya. The Teaching function menyediakan informasi baru yang relevan dengan tugas dan kebutuhan guru, supaya guru mengetahui apa yang terjadi dengan dunia pendidikan di masa ini yang berpengaruh terhadap pembelajaran. The Role of consultan merupakan bagian terpenting dari fungsi seorang supervisor dengan memberikan nasihat dan solusi terhadap masalah yang dihadapi oleh guru. Supervisor pengajaran lebih berperan sebagai gurunya guru. Mereka adalah orang-orang yang siap membantu kesulitan guru dalam melaksanakan proses pembelajaran.

Sehubungan dengan itu, Suhardan (2010, h. 55-56) mengatakan "Supervisor harus cakap dan terampil memberi bantuan dalam memecahkan berbagai kesulitan yang dihadapi guru dalam menjalankan tugas utamanya, cepat memahami ide seorang guru untuk diterjemahkan dalam perbaikan tugasnya, sehingga ide tersebut dapat dilaksanakan sesuai dengan keinginan dan kemampuan guru yang menjalankannya".

Pelayanan pendidikan dalam bentuk supervisi yang dilakukan oleh supervisor pada dasarnya adalah untuk memfasilitasi, membantu dan memberikan solusi dari setiap persoalan yang dialami dan dirasakan oleh guru. Pelayanan supervisi ini membawa misi utama yaitu memberi pelayanan kepada guru untuk mengembangkan mutu pembelajaran, memfasilitasi guru agar dapat menjalankan pembelajaran secara kreatif. Pelayanan supervisi yang efektif dari supervisor akan berdampak pada peningkatan kualitas dan kreativitas guru dalam mengelola dan memenej kegiatan pembelajaran. Pembelajaran yang berkualitas akan memberi-kan hasil yang berkualitas pula yaitu terciptanya nuansa pembelajaran aktif, inovatif, kreatif, dan efektif.

Hasil penelitian terdahulu menunjukkan bahwa supervisi sangat membantu bagi guru dalam memecahkan permasalahan berkaitan dengan proses pembelajaran baik dalam hal administratif maupun pada tahap implementasi dan 
evaluasi serta mampu memberikan motivasi bagi guru untuk meningkatkan kinerja dalam proses pembelajaran (Suryani, 2015). Selain itu, melalui optimalisasi supervisi yang dilakukan kepala sekolah, dapat memotivasi guru untuk meningkatkan kreativitas dalam pembelajaran (Oktavia, 2014).

Supervisor yang berkualitas dan efektif dalam memberikan pelayanan dan dukungan supervisi maka akan berdampak pada kualitas guru sehingga guru dapat berkreasi untuk melahirkan ide-ide dalam bentuk inovasi pembelajaran dan pada akhirnya mutu dari hasil pendidikan yang diharapkan dapat tercapai. Pada intinya bahwa kunci dari keberhasilan pendidikan adalah bagaimana guru sebagai central of excelent dalam mengelola pembelajaran harus senantiasa men-dapat pelayanan supervisi secara efektif dari supervisor. Sukses pembelajaran adalah akumulasi dari sukses peserta didik. Karena itu, masalah mutu pembelajaran merupakan masalah esensial yang sangat ditentukan oleh kualitas mengajar guru. Salah indikator kualitas mengajar guru dapat dilihat dari kreativitasnya dalam mengelola pembelajaran yang dimulai dari perencanaan, pelaksanaan maupun evaluasi pembelajaran. Dalam Undang-Undang RI Nomor 20 Tahun 2003, tentang Sistem Pendidikan Nasional menyatakan bahwa tugas pokok profesional guru yaitu merencanakan pembelajaran, melaksanakan pembelajaran, melakukan evaluasi, melaksanakan analisis hasil evaluasi belajar peserta didik serta melakukan perbaikan dan pengayaan, perlu mendapat pengawasan dan pembinaan terus menerus dan berkelanjutan dari pengawas yang profesional untuk memperbaiki mutu pembelajaran. Berdasarkan amanah undang-undang tersebut di atas, terwujudnya guru yang profesional, kreatif dan inovatif dalam memenej pembelajaran tidak terlepas dari pengawasan dan pembinaan oleh supervisor secara efektif dan terancana. Kreativitas guru pendidikan agama islam dapat dimaksimalkan dengan melalui pendampingan supervisor, kepala sekolah maupun sesama rekan kerja pada tingkat satuan pendidikan masing-masing. Kreativitas seorang guru sangat berpengaruh terhadap peningkatan mutu pendidikan. Kreativitas guru tidak terlepas dari kualitas kinerja guru. Menurut Sudarman Danim (2009, h. 25) kinerja seseorang dipengaruhi oleh beberapa faktor seperti: abiity, capacity, held, incentive, envirolment dan validity.

Sejalan dengan hal tersebut, maka guru PAI SMA Negeri di Kabupaten Sinjai Provinsi Sulawesi Selatan dituntut untuk lebih kreatif dalam melaksanakan pembelajaran dengan perencanaan, pelaksanaan, dan evaluasi pembelajaran yang optimal. Pengawasan terhadap pembelajaran tentu berkaitan dengan penguasaan terhadap perencanaan, strategi dan skenario pengajaran, media pembelajaran, referensi, teknologi pendidikan, evaluasi belajar. Inovasi dan kreativitas pembelajaran Guru PAI SMA Negeri di Kabupaten Sinjai Provinsi Sulawesi Selatan perlu ditingkatkan oleh pengawas sesuai peran, fungsi dan tanggung jawab pengawas, sebagaimana amanah Permendiknas Nomor 12 Tahun 2007 tentang 
Standar Pengawas Sekolah/Madrasah dan Permenag Nomor 2 Tahun 2012 tentang pengawas madrasah dan pengawas Pendidikan Agama Islam di Sekolah.

Berdasarkan pengamatan, kegiatan Guru PAI dalam perencanaan dan pelaksanaan pembelajaran belum dapat menunjukkan peningkatan kreativitas. Guru masih terlihat tidak berperan secara mandiri hal ini dapat dilihat mereka dalam belum mampu membuat perencanaan pembelajaran secara mandiri, masih sering mengcopy paste perencanaan pembelajaran dari guru yang berasal dari sekolah yang berbeda, terbatasnya pengetahuan, kurangnya pembinaan dan pelatihan, dan kegiatan supervisi yang belum optimal dilakukan oleh supervisor. Supervisor hanya datang berkunjung tanpa ada layanan pembinaan dan kontribusi pemikiran yang dapat memberikan konsep baru terhadap pelaksanaan pembelajaran guru PAI bahkan volume kunjungan supervisor pun masih terhitung minim, itupun pada supervisi administrasi dan yang lebih parah lagi supervisor tidak sesuai dengan kualifikasi dan tidak memiliki kompetensi kepengawasan. Keadaan ini menunjukkan bahwa supervisi yang dilakukan oleh supervisor belum memberikan makna yang signifikan dan fokus dalam meningkatkan kreatvitas guru sehingga prinsip pengawasan pada satuan pendidikan tidak mewujudkan keadaan yang dapat memberikan nilai atau perubahan mendasar terhadap guru PAI dalam membuat perencanaan dan pelaksanaan pembelajaran terutama memberikan motivasi dan pengetahuan secara signifikan terhadap guru agar lebih proaktif, kreatif secara mandiri dalam proses pelaksanaan pembelajaran.

Berdasarkan fakta di lapangan, penulis menggaris bawahi bahwa penyebab guru PAI SMA Negeri di Kabupaten Sinjai Provinsi Sulawesi Selatan belum memiliki kreativitas dalam pelaksanaan proses pembelajaran yang baik karena pertama, supervisor PAI tidak memberikan layanan supervisi berdasarkan kompetensinya kepada guru sehingga guru bersikap apriori terhadap pelaksanaan pembelajaran. Kedua, guru kehilangan kesadaran bahwa mengatur pembelajaran adalah cara strategis agar proses pembelajaran berhasil dan memenuhi harapan tujuan pendidikan baik tujuan pembelajaran, tujuan institusional serta tujuan pendidikan nasional. Ketiga, guru belum memiliki rasa terpanggil dalam berbuat bagian dari tanggung jawabnya, guru masih senang dengan budaya ketergantungan terhadap yang lain, dia lupa bahwa perencanaan pembelajaran itu terimplisit dalam amanah Peraturan Pemerintah Nomor 19 Tahun 2005 Pasal 19, Ayat 3, “Setiap satuan pendidikan melakukan perencanaan proses pembelajaran, pelaksanaan proses pembelajaran, penilaian hasil pembelajaran, dan pengawasan proses pembelajaran untuk terlaksananya proses pembelajaran yang efektif dan efisien". Keempat rendahnya pembinaan dan pelatihan secara berkala dan kontinuitas yang dilakukan supervisor terhadap guru. Dengan fakta ini maka sangat diperlukan efektivitas kinerja supervisor untuk menjalankan tugas dan fungsinya dalam pembinaan terhadap guru secara maksimal dan berkelanjutan. 
Berdasarkan realitas tersebut, maka menarik untuk diteliti dan dikaji lebih mendalam tentang kinerja supervisor dan kreativitas guru PAI di SMA Negeri 1 Sinjai.

\section{METODE PENELITIAN}

Jenis penelitian ini adalah penelitian kualitatif. Penelitian ini berlokasi di Kab. Sinjai dan Kantor Kementerian Agama Kabupaten Sinjai. Fokus penelitiannya adalah berkaitan dengan kinerja supervisor untuk meningkatkan kreativitas guru PAl yang di tempatkan di SMA Negeri Kabupaten Sinjai. Sumber data yaitu primer dan sekunder, data primer berasal dari informan utama supervisor PAl tingkat SMA Kabupaten Sinjai terdiri dari 4 orang, dan informan lainnya guru PAI 13 orang, serta 2 orang kepala sekolah. Data sekunder diperoleh dari informan pendukung yaitu guru yang merasakan langsung manfaat pelaksanaan supervisi. Pada teknik pengumpulan data observasi, data yang akan diperoleh berupa hasil pengamatan aktivitas para supervisor PAI berupa pelaksanaan rencana kerja dan kegiatan bimbingan supervisor pada guru PAl. Teknik pengumpulan data dalam bentuk wawancara, dimaksudkan untuk menggali infomasi yang berhubungan dengan rencana kerja supervisor dalam meningkatkan kreatiivitas guru PAI. Teknik pengumpulan data dalam bentuk dokumentasi, dimaksudkan untuk mendapatkan hal-hal yang tersedia dalam bentuk dokumen (tertulis) yang sulit didapatkan melalui wawancara. Instrumen penelitian ini yang utama adalah peneliti itu sendiri, selanjutnya pedoman wawancara, dan alat perekam untuk dokumentasi. Teknik analisis data yang digunakan yaitu reduksi data, penyajian data dan penarikan kesimpulan atau verifikasi dengan menggunakan metode analisis teknik deskriptif eksploratif, dan menggunakan metode induktif kualitatif.

\section{HASIL PENELITIAN DAN PEMBAHASAN}

\section{Kinerja Supervisor untuk Meningkatkan Kreativitas Guru Kinerja Penyusunan Program Supervisor}

Supervisor SMA Negeri Kabupaten Sinjai dalam melaksanakan tugas-tugasnya, senantiasa berpatokan pada tugas-tugas yang melekat kepadanya sebagai seorang supervisor. Hal ini dikemukakan seorang supervisor bernama Nurdin (52 tahun) mengemukakan bahwa dalam melaksanakan tugas-tugas sebagai supervisor, kami senantiasa mengacu pada tugas-tugas yang memang telah ditetapkan. Tugas-tugas tersebut meliputi empat tugas, yaitu penyusunan perencanaan supervisoran, pembinaan, penilaian, dan pemantauan.

Lebih lanjut, Bapak Ambo Tang (49 tahun) sebagai salah seorang supervisor memberikan perincian tentang tugas-tugas mereka yang melekat sebagai seorang supervisor. Beliau mengemukakan bahwa: dalam penyusunan program perencanaan supervisoran, kami para supervisor Pendidikan Agama Islam yang kebetulan ditempatkan di satuan pendidikan SMA Kabupaten Sinjai dalam melaksanakan tugas atau program kerja kami; pertama-tama kami melakukan penyusunan program perencanaan supervisoran. Pada tataran ini kami menyusun program tahapan yang kami sebut sebagai protap, kemudian program semesteran atau prosem, dan 
program tahunan atau protah. Jadi, kami sebagai supervisor bersepakat tidak datang begitu saja ke setiap sekolah binaan kami.

Berdasarkan pernyataan tersebut dapat dipahami bahwa supervisor dalam melaksanakan tugasnya tidak berdasar pada ungkapan lama "tiba masa tiba akal asal pekerjaan lancar". Tetapi mereka telah menyusun perencanaan yang matang. Keseriusan supervisor dalam membuat perencanaan juga terlihat pada dokumendokumen yang mereka arsipkan untuk menjadi acuan pelaksanaan tugas mereka. Analisis dokumen yang dilakukan oleh peneliti menunjukkan adanya programprogram perencanaan yang terangkum dalam buku kesupervisoran PAI di Kabupaten Sinjai yaitu (1) Program Tahapan (Protap) terdiri dari rapat intern supervisor, peningkatan mutu pendidikan, dan penentuan standar kegiatan pendidikan; (2) Program Semesteran (Prosem) terdiri dari rapat koordinasi dan mengaktifkan forum MGMPAl; (3) Program Tahunan (Protah) terdiri dari menjalin kerjasama dan kegiatan pelatihan atau diklat penguasaan IT. Hal ini sejalan sejalan dengan hasil penelitian yang dilakukan oleh Wahidah (2015) yang mengemukakan bahwa program supervisi pengajaran telah disusun secara matang melalui bimbingan terhadap tugas-tugas guru, seperti penyusunan program pengajaran, penyiapan perangkat pembelajaran (Satuan acuan pelajaran, rencana pembelajaran, alat evaluasi, penyiapan media pembelajaran dan lain-lain).

\section{Kinerja Pelaksanaan Pengawasan Supervisor}

Data yang ditemukan di lapangan menunjukkan adanya keseriusan supervisor yang dimandat dalam melakukan pekerjaan kesupervisoran. Hal ini didasarkan pada pengamatan peneliti yang senantiasa mendapati supervisor di sekolah yang mereka bina. Peneliti mengetahui jadwal kedatangan supervisor melalui guru yang mereka bina pada satuan pendidikan (SMA). Melalui informasi tersebut, peneliti berusaha agar lebih dahulu berada di tempat sebelum supervisor datang. Pemenuhan setiap jadwal yang telah disepakati antara guru dan supervisornya memberikan indikasi adanya keseriusan supervisor untuk melakukan tugasnya sebagai supervisor. Sejalan dengan hal tersebut, seorang supervisor bernama Tamsil (50 tahun) mengemukakan bahwa selama saya ditetapkan sebagai supervisor, maka langkah pertama yang saya lakukan adalah mendatangi seluruh sekolah-sekolah yang menjadi binaan saya. Setiap sekolah yang saya datangi tersebut, saya melakukan perjanjian dengan guru untuk melakukan pertemuan rutin secara terjadwal.

Hal tersebut memberikan gambaran adanya keinginan yang kuat bagi seorang supervisor untuk melakukan tugas-tugasnya sebagai supervisor. Untuk melancarkan tugas-tugas mereka, supervisor melakukan "kontrak pertemuan" dengan para gurunya. Dengan demikian, guru dan supervisor dapat bertemu sesuai dengan jadwal tersebut. Hal ini juga dapat meminimalisir alasan bahwa supervisor datang secara mendadak, sehingga guru tidak memiliki persiapan dan sebagainya. Bahkan dengan perjanjian ini dapat memperkecil kemungkinan tidak bertemunya antara guru dan supervisor. 
Dalam pengamatan peneliti, program pembinaan yang dilakukan oleh supervisor dalam mencapai mutu maupun pemenuhan standar pendidikan nasional dilakukan secara face to face, yaitu berhadapan langsung dengan guru-guru PAI yang menjadi binaannya. Menurut Ramli (50 tahun) dari komunikasi yang terbangun para guru mengutarakan apa yang menjadi kendala-kendala mereka, khususnya yang berkaitan dengan pemenuhan standar pendidikan. Dengan demikian, sebagai supervisor kami mengetahui keadaan guru dan sekaligus dapat memberikan umpan balik berupa solusi alternative. Selain program binaan dalam bentuk face to face, para supervisor melakukan program binaan dalam bentuk forum yang cukup besar seperti musyawarah guru mata pelajaran MGMP. Dalam forum tersebut tampak semua supervisor terlibat dan hadir memberikan materi dan melakukan diskusi. Pada saat kegiatan musyawarah guru mata pelajaran (MGMP) berlangsung, para supervisor senantiasa mendampingi para guru, bahkan mereka terlibat dalam pemberian materi. Ketika seluruh materi telah tersampaikan, diskusi pun dilakukan. Dalam diskusi ini, supervisor memberikan masukan-masukan atas problem yang muncul di dalam musyawarah guru mata pelajaran (MGMP).

Berdasarkan pengamatan dan pernyataan tersebut, dapat dikatakan bahwa kinerja Supervisor PAI tingkat SMA pada Kementerian Agama Kabupaten Sinjai dalam hal pembinaan optimal untuk meningkatkan kemampuan profesional guru binaannya. Tugas-tugas kesupervisoran telah diimplementasikan di lapangan dengan segenap kemampuan yang mereka miliki secara profesional, kontinyu atau terus-menerus, dan teratur. Meskipun belum sepenuhnya tercapai karena masih terdapat program kerja yang tertunda. Hal ini sejalan dengan hasil penelitian yang dilakukan oleh Kadarwati (2016, h. 103) yang mengatakan bahwa "Membimbing dan membina guru dalam kegiatan supervisi akademik dapat meningkatkan kemampuan profesional guru dalam proses pembelajaran."

\section{Kreativitas Guru}

Menurut Kristiawan dan Rahmat (2018, h. 374) pada dasarnya kompetensi profesionalisme guru dapat dibagi atas tiga bidang, yaitu: bidang kognitif, bidang sikap, dan bidang perilaku. Apabila kompetensi tersebut inheren pada diri seorang guru, maka proses pendidikan dan belajar mengajar pasti akan berjalan dengan baik, dan tentunya kualitas pendidikan pun akan dapat dicapai sesuai harapan. Akan tetapi, dengan jujur harus diakui bahwa guru PAI, khususnya dalam lingkup SMA di Kabupaten Sinjai, hingga saat ini belum mampu berakselerasi dengan perkembangan yang begitu pesat. Hal ini senada dengan yang dikemukakan oleh salah seorang supervisor yang mengatakan bahwa mereka masih mengajar dengan gaya lama, misalnya datang, duduk mengabsen memberikan salinan sesuai materi sampai dua jam pelajaran berakhir. Mereka masih mengandalkan model pembelajaran masa lalu yang bertumpu pada salinan-salinan materi dan penjelasan yang juga bertumpu pada guru (teacher oriented). Dengan demikian, proses pembelajaran menjadi monoton. Pengamatan peneliti juga menemukan bahwa guru- 
guru PAI yang menerapkan model pembelajaran seperti ini pada umumnya guru-guru PAl yang sudah terbilang senior. Mereka hanya menerangkan apa sudah jelas-jelas ada materinya dalam buku. Mereka tidak memberikan contoh-contoh yang lebih kontekstual sesuai dengan zaman sekarang atau hal-hal yang sedang up to date.

Berdasarkan pernyataan dan pengamatan tersebut memberikan gambaran kondisi objektif guru Pendidikan Agama Islam yang tersebar pada beberapa SMA di kabupaten Sinjai. Guru-guru tersebut dapat dikatakan tidak memiliki kreatifitas dalam merancang dan meramu pembelajaran mereka di dalam kelas. Bahkan mereka tidak mampu melakukan sinkronisasi dengan media pembelajaran dan kondisi terkini di sekitar peserta didik.

Berkait dengan hal tersebut, seorang supervisor bernama Tamsil (50 Tahun) mengemukakan bahwa untuk menyikapi kondisi guru Pendidikan Agama Islam yang saya nilai tidak kreatif dalam mengembangkan pembelajaran mereka di kelas, maka saya berupaya untuk melakukan pendampingan secara intensif. Mulai dari dari perumusan dan tata cara pembuatan RPP, perbaikan strategi pembelajaran PAI sampai kepada pengelolaan kegiatan pada tatap muka peserta didik. Saya melakukan hal ini karena keberhasilan suatu pembelajaran kemungkinan diawali dengan beberapa kegiatan informatif dari guru kepada peserta didik atau dari peserta didik kepada guru. Kegiatan informatif tersebut hendaknya dilakukan secara terorganisir pada awal pertemuan pertama atau dengan istilah tatap muka pertama, sehingga peserta didik mengetahui secara tepat kapabilitas apa yang seharusnya peserta didik miliki setelah mengikuti mata pelajaran PAI dalam satu kurun waktu tertentu, sehinga kegiatan yang perlu diorganisir dalam prosesi pembelajaran di SMA Kabupaten Sinjai. Selain itu, saya melakukan pembimbingan untuk melakukan pendeteksian karakteristik peserta didik, penyampaian garis besar program mata pelajaran PAl yang meliputi kerangka isi buku teks pelajar dan lain sebagainya. Hal ini sejalan dengan hasil penelitian (Aziz, 2019) agar kreativitas guru meningkat dalam pembelajaran, hendaknya kompetensi kepala sekolah sebagai supervisor perlu dioptimalkan agar mampu menjalankan fungsi-fungsi kepemimipian sesuai dengan bidang garapannya.

Berdasarkan keterangan di atas, maka dapat dipahami bahwa supervisor dalam menjalankan tugas dan tanggung jawabnya telah mengadakan upaya secara terus menerus untuk membenahi segala hal untuk meningkatkan kreativitas guru PAI di SMA Kabupaten Sinjai. Para supervisor tidak tinggal diam dalam meningkatkan mutu pengajaran yang diterapkan oleh guru sebagai penopang utama keberhasilan prestasi belajar siswa. Dalam pengamatan peneliti, guru-guru PAl yang telah mendapatkan bimbingan dari supervisor memiliki kreativitas dalam pengelolaan interaksi belajar mengajar. Hal ini terlihat dari cara guru menciptakan suasana kelas yang lebih hidup dan dinamis. Peserta didik memiliki antusias dan tampak mereka sangat senang dibandingkan dengan sebelumnya. Peneliti melihat adanya interaksi antara guru dan peserta didik, begitupula antar peserta didik. Begitupula dalam 
kreativitas dalam menyampaikan program pengajaran kepada peserta didik. Tampak guru PAI membuat kuis-kuis kecil kepada peserta didik yang mengarahkan mereka kepada apa yang akan mereka pelajari pada saat itu. Setelah permainan kecil tersebut, guru PAI pun memberikan makna dari apa yang telah mereka lakukan sekaligus menyampaikan hubungannya dengan materi yang akan dipelajari.

Berdasarkan pernyataan tersebut dapat dipahami bahwa dengan adanya pembinaan yang kontinyu dilakukan oleh supervisor, para guru PAl mampu menumbuhkan kreativitasnya dalam mengelola pembelajaran. Mereka mampu mengkreasikan situasi kelas agar kelas pembelajaran mereka menjadi kelas yang hidup dan penuh semangat. Interaksi antara guru dengan siswa dapat terjalin dengan baik, begitupula interaksi antara peserta didik dengan peserta didik lainnya juga terbangun dengan baik. Selain itu, pemanfaatan media pembelajaran yang diterapkan oleh guru PAI juga sudah berjalan. Para guru PAI dalam melaksnakan proses belajar mengajar di kelas telah menggunakan media pembelajaran. Media pembelajaran yang dipergunakan cukup bervariasi. Kadang menggunakan media gambar berbentuk poster, tekadang juga menggunakan media dalam bentuk power point. Oleh karena itu, dapat dipahami bahwa telah terjadi peningkatan kreativitas guru dalam melaksanakan proses belajar mengajar di kelas dengan menggunakan media pembelajaran.

Berdasarkan dari uraian yang telah dijelaskan, maka dapat dipahami bahwa Supervisor dalam melalui beberapa program yang telah mereka lakukan berhasil mengantar para guru mata pelajaran Pendidikan Agama Islam (PAI) sedikit demi sedikit untuk meningkatkan kemampuan kreativitasnya sebagai guru yang sesungguhnya. Guru yang memiliki memiliki kompetensi dalam mengajar mulai dari perencanaan sampai kepada kemampuan untuk melangsungkan proses pembelajaran dengan baik. Hal ini sejalan dengan hasil penelitian yang dilakukan oleh Pardede dan Alim (2020) mengatakan bahwa melalui beberapa upaya yang dilakukan oleh supervisor kepala sekolah berhasil meningkatkan kreativitas guru, pada siklus ke-3 dengan hasil $76,42 \%$ berada pada kriteria baik.

\section{Faktor Pendukung dan Penghambat Supervisor dalam Meningkatkan Kreativitas Guru}

Peningkatan kreativitas sesuai dengan tuntutan pendidikan mengalami berbagai faktor hambatan namun di balik hambatan itu peluang dan harapan sebagai faktor pendukung juga tetap ada untuk mendukung peningkatan kreativitas guru. Faktor pendukungnya antara lain: (1) Adanya pengaturan standarisasi kesupervisoran. Standar pelaksanaan tugas supervisor sesungguhnya merupakan faktor pendukung untuk menjadi basis peningkatan kreativitas guru. Hal ini disebabkan pelaksanaan standar kerja seorang supervisor jika dikerjakan secara konsisten dapat meningkatkan kreativitas guru. Hal ini disampaikan oleh salah seorang supervisor yang bernama Nurdin (52 tahun) mengatakan bahwa tugas supervisor itu sudah jelas, bahkan menjadi standar kinerjanya. Pernyataan ini 
merupakan gambaran bahwa dengan adanya standar kesupervisoran yang dilakukan secara konsisten, maka harapan untuk membina guru secara berkelanjutan dari seorang supervisor terbuka lebar. Ini berarti kemampuan dan kreativitas seorang guru dapat dikembangkan dan ditingkatkan sampai memenuhi standar kompetensi seorang guru; (2) Adanya perhimpunan. Faktor pendukung lain adalah adanya perhimpunan untuk semua guru dan kepala sekolah, hal ini dapat dilihat dari upaya lain dilakukan Supervisor dalam meninngkat kreativitas guru SMA di Kabupaten Sinjai adalah sebagaimana yang dikemukakan oleh Tamsil (50 tahun) yang mengatakan bahwa upaya yang dilakukan adalah membangun hubungan koordinasi dengan membentuk wadah untuk guru yang disebut KKG dan MGMP, kesemuanya itu dikoordinasikan langsung oleh Supervisor. Berdasarkan pernyataan tersebut, dapat dipahami bahwa melalui perhimpunan yang dikoordinir langsung oleh supervisor memberikan dampak posistif bagi guru Pendidikan Agama Islam (PAI). Dampak positif tersebut berupa penguatan kemampuan seorang guru Pendidikan Agama Islam (PAI) pada satu sisi dan pada sisi yang lain memberikan kemudahan bagi supervisor untuk melakukan pembinaan lebih lanjut kepada guruguru yang berada dalam pengawasan mereka.

Adapun faktor penghambat, yaitu: (1) Jumlah sekolah binaan yang terlalu banyak. Berdasarkan observasi dilapangan, ditemukan tantangan sebagai faktor penghambat yang dihadapi Supervisor Kementerian Agama Kabupaten Sinjai, di antaranya jumlah SMA dan sederajat mencapai 37 buah, sebaran SMA yang tidak merata dengan medan yang cukup luas. Minimnya jumlah supervisor, sehingga menyebabkan kegiatan kesupervisoran tidak terlalu fokus karena harus melayani banyak sekolah termasuk melayani kepengawasan di sekolah pendidikan dasar (SMP/MTs, SD/MI) dan kurangnya minat kepala sekolah/guru yang berprestasi mutasi ke jabatan supervisor. Hal ini berarti satu orang pengawas harus membina sembilan SMA dan sederajat yang tersebar dengan medan yang cukup jauh dari domisilinya. Jadi, rasio antara supervisor dengan sekolah yang bina adalah 1 : 9. Perbandingan cukup besar jika dihubungkan dengan tugas seorang supervisor. Hal ini dipertegas oleh salah seorang supervisor yang bernama Tamsil (50 tahun) mengatakan bahwa saya sebagai supervisor harus menangani 9 SMA dan sederajat yang ada di Kabupaten Sinjai, dan sekolah ini tidak berdekatan jaraknya; (2) Kesibukan supervisor diluar program pengawasan. Jumlah supervisor Kementrian Agama Kabupaten Sinjai tingkat SMA sangat minim, yaitu hanya 4 orang supervisor. Sementara penugasan mereka tidak hanya di SMA dan yang sederajat tetapi juga pada jenjang sekolah tingkat dasar yang tersebar dengan medan yang cukup jauh dari domisilinya. Belum lagi kesibukan diluar program kepengawasan sebagai tugas pokoknya. Seorang supervisor bernama Sitti Ramlah Saleh (46 tahun) mengemukakan bahwa sebenarnya selain tugas pokok sebagai supervisor kami juga memiliki kesibukan lain yang kadang menghambat tugas pokok saya dan yang paling dirasakan ketika mengisi acara tak terduga seperti takziah saat ada keluarga yang 
meninggal, mengisi khutbah jumat dan juga menghadiri kondangan keluarga dan rekan sejawat lainnya; (3) Masih minimnya jumlah supervisor. Kurangnya minat kepala sekolah mutasi ke jabatan supervisor dalam pandangan peneliti juga merupakan kendala. Hal ini disebabkan pengamatan peneliti yang menghitung jumlah supervisor yang sangat minim dengan jumlah sekolah yang harus dibina memiliki perbandingan yang tidak berimbang. Seorang supervisor bernama Ramli (50 tahun) mengemukakan bahwa sebenarnya jumlah supervisor untuk Sekolah Menengah Atas (SMA) sangat sedikit jika dibandingkan dengan jumlah sekolah yang harus dibina; (4) Persepsi guru terhadap kegiatan supervisi masih kurang baik. Kegiatan supervisi yang dilakukan oleh supervisor guru PAl memiliki perbedaan pandangan di antara para guru. Hal ini dikemukakan oleh seorang guru yang bernama Abd. Razak (53 tahun) mengemukakan bahwa di antara kami para guru PAI memandang posisi supervisor dalam melakukan supervisi juga berbeda-beda.

Berdasarkan uraian tersebut dapat dipahami bahwa di samping adanya pendukung terlaksananya pembinaan kepada guru PAI SMA di Kabupaten Sinjai untuk meningkatkan kreativitas guru, juga terdapat faktor penghambat yang senantiasa merintangi bahkan memperlambat kerja-kerja seorang supervisor. Oleh karena itu, perlu mendapatkan perhatian, terutama pihak pengambil kebijakan untuk menyikapi dan memberikan solusi alternatif. Solusi yang ditawarkan dalam mengatasi hal tersebut, yaitu: (1) Memanfaatkan kegiatan MGMP PAI untuk melaksanakan pembinaan secara berkelompok. Melakukan pembimbingan secara berkala melalui pembinaan secara kelompok sesuai wilayah kerja supervisor. Pembinaan secara berkelompok ini dilakukan dengan memamfaatkan MGMP PAI yang melakukan MGMP satu kali dalam sebulan secara roling yang tahun-tahun sebelumnya hanya dilaksanakan secara terpusat dikabupaten. Perolingan dimaknai sebagai pergeseran tempat MGMP sesuai wilayah kerja supervisor didasarkan pada wilayah kerja mereka yang relatif dekat dengan sekolah binaannya; (2) Memanfaatkan hari sabtu. Diharapkan dengan adanya melakukan supervisi pada hari sabtu ini pendampingan dan pengawasan untuk pembinaan guru-guru binaan bisa diatasi; (3) Memanfaatkan kesempatan diluar program kerja untuk melakukan pembinaan. Membangun silaturrahmi terhadap guru yang memiliki persepsi yang kurang baik tersebut dengan cara face to face untuk mengalihkan persepsi tersebut sekaligus membangkitkan semangatnya agar mampu menjadi guru profesional kedepan.

\section{PENUTUP/SIMPULAN}

Kinerja supervisor PAI di SMA Negeri Kabupaten Sinjai terjabarkan dalam penyusunan perencanaan program supervisor yang telah tersusun secara matang dan pelaksanaan pengawasan supervisor telah diimplementasikan di lapangan secara kontinyu atau terus-menerus, dan teratur untuk meningkatkan kemampuan professional guru. Kreativitas guru PAI di SMA Negeri Kabupaten Sinjai telah 
mengalami peningkatan melalui beberapa program yang telah disusun secara matang oleh supervisor.

Faktor pendukung supervisor dalam meningkatkan kreativitas guru PAI SMA Negeri di Kabupaten Sinjai Provinsi Sulawesi Selatan yaitu adanya pengaturan standarisasi kesupervisoran dan adanya penghimpun. Adapun faktor penghambat supervisor yaitu jumlah sekolah binaan yang terlalu banyak, kesibukan supervisor diluar program pengawasan, masih minimnya jumlah supervisor, dan persepsi guru terhadap kegiatan supervisi masih kurang baik.

\section{DAFTAR PUSTAKA}

Aziz, H. (2019). Persepsi Guru PAl Tentang Pelaksanaan Supervisi Oleh Kepala Sekolah dengan Kreativitas Guru dalam Mengajar (Penelitian Guru PAI di SMP Se-Kecamatan Cileunyi Kabupaten Bandung). AL-MURABBI: Jurnal Studi Kependidikan Dan Keislaman, 5(2), 185-196.

Damopolii, M. (2011). Pesantren Modern IMMIM Pencetak Muslim Modern (Cet. I). Rajawali Pers.

Danim, Sudarman. (2009). Inovasi Pendidikan dalam Upaya Peningkatan Profesionalisme Tenaga Kependidikan. Pustaka Setia.

Danim, Sudarwan, dan Khairil. (2010). Profesi Kependidikan (Cet. I). Bandung: Alfabeta.

Getteng, A. R. (2010). Menuju Guru Profesional dan Beretika (Cet. III). Yogyakarta: Graha Guru.

Kadarwati, A. (2016). Peningkatan Kualitas Pembelajaran Melalui Supervisi Akademik. Jurnal Studi Sosial, 1(2), 103-120. ejournal.unipma.ac.id/index.php/gulawentah/article/download/1034/919

Kristiawan, M., \& Rahmat, N. (2018). Peningkatan Profesionalisme Guru Melalui Inovasi Pembelajaran. Jurnal Iqra' : Kajian IImu Pendidikan, 3(2), 373-390. https://doi.org/https://doi.org/10.25217/ji.v3i2.348

Makawimbang, J. H. (2011). Supervisi dan Peningkatan Mutu Pendidikan (Cet. I). Bandung: Alfabeta.

Nurdin, M. (52 tahun), Supervisor tingkat Menengah di SMA Kabupaten Sinjai. Wawancara, Sinjai, 12 Agustus 2019.

Nurhayati, Siraj, A., \& Yaumi, M. (2020). Pengaruh Kompetensi Supervisi dan Manajerial Kepala Sekolah terhadap Mutu Pendidikan di Madrasah Tsanawiyah Se-Kecamatan Gantarang Kabupaten Bulukumba. Jurnal Idaarah, IV(1), 60-76. https://doi.org/https://doi.org/10.24252/idaarah.v4i1.14057

Oktavia, Y. (2014). Usaha Kepala Sekolah dalam Meningkatkan Kreativitas Guru 
dalam Pembelajaran di Sekolah Dasar. Jurnal Administrasi Pendidikan, 2(1).

Pandong, A. (2013). Jabatan Fungsional Pengawas. Jakarta: Badan dan Diklat Kementerian Pendidikan Nasional.

Pardede, L., \& Alim. (2020). Peningkatan Kreativitas Guru Melalui Peran Pengawas dalam Memahami Fungsi Tugas Kepala Sekolah di SMA Negeri 17 Medan. Pendidikan Religious, 2(1), 1-12.

Ramli. (50 tahun), Supervisor tingkat Menengah di SMA Kabupaten Sinjai, Wawancara, Sinjai, 09 Agustus 2019.

Sagala, S. (2009). Administrasi Pendidikan Kontemporer (Cet. V). Bandung: Alfabeta.

Saleh, Sitti Ramlah. (46 tahun), Guru PAI SMA Negeri 4 Kabupaten Sinjai, Wawancara, Sinjai, 27 Agustus 2019.

Sahertian, P. A. (2010). Konsep Dasar dan Teknil Supervisi Pendidikan dalam Rangka Pengembangan Sumber Daya Manusia. Jakarta: Rineka Cipta.

Suhardan, D. (2010). Supervisi Profesional: Layanan dalam Meningkatkan Mutu Pengajaran di Era Otonomi Daerah (Cet. III). Bandung: Alfabeta.

Suryani, C. (2015). Implementasi Supervisi Pendidikan dalam Meningkatkan Proses Pembelajaran di MIN Sukadamai Kota Banda Aceh. Jurnal IImiah DIDAKTIK, 16(1), 23-42. https://doi.org/http://dx.doi.org/10.22373/jid.v16i1.585

Tamsil. (50 tahun), Supervisor tingkat Menengah di SMA Kabupaten Sinjai. Wawancara, Sinjai, 09 Agustus 2019.

Tang, Ambo. (49 tahun), Supervisor tingkat Menengah di SMA Kabupaten Sinjai. Wawancara, Sinjai, 14 Agustus 2019.

Wahidah, S. (2015). Sekolah dalam Meningkatkan Kinerja Guru di SMK Negeri 1 Banda Aceh. Jurnal Magister Administrasi Pendidikan, 3(3), 50-57. 